Arab Univ. J. Agric. Sci., Ain Shams Univ., Cairo, 13(3), 989 - 996, 2005

\title{
DISSIPATION RATE OF CERTAIN INSECTICIDES ON TOMATO PLANTS AND THEIR BIORESIDUAL ACTIVITIES AGAINST SPODOPTERA littoralis (BOISD.)
}

[67]

\author{
Nevein S. Ahmed ${ }^{1}$ and Amal A. Hassanein ${ }^{1}$
}

\begin{abstract}
Field trials were conducted at El-Gharbia governorate to determine the insecticidal activities of chlorpyrifos-methyl, profenofos and methomyl on tomato plants against the cotton leaf-worm (Spodotera littoralis). Data showed the high initial mortality $(100,100$ and 100\%) against the second and the fourth instars larvae with reasonable persistence. The residues of these insecticides on fruits of the sprayed and contaminated tomato plants were determined by GLC and HPLC, with recoveries of 100,100 and $94.58 \%$, respectively. The initial deposits of chlorpyrifos-methyl, profenofos and methomyl were 2.10, 2.58 and $20.11 \mathrm{ppm}$, while decreased to $0.19,1.41$ and $0.33 \mathrm{ppm}$ after 3,1 and 13 days from spraying, respectively, such residue levels are below the maximum residue level (MRL). The estimated half-life values $\left(\mathrm{t}_{0.5}\right)$ were $0.4898,1.026$ and 1.1867 days for the same insecticides, respectively.
\end{abstract}

Key words: Insecticides, Cotton leaf-worm, Chlorpyrifos-methyl, Profenofos, Methomyl, Residues, Tomota plants

\section{INTRODUCTION}

The cotton leaf-worm, Spodoptera littoralis (Boisd) is one of the most important insect pests in Egypt. It attacks cotton, vegetable and ornamentals. Many farmers are using the organophosphorus (chlorpyrifos-methyl \& profenofos) and the carbamate methomyl to control this serious pest (Tomlin, 2000). Tomato (Lycopersicon esculentum) is considered to be an important among fresh eaten crops.
The present study was undertaken to determine the insecticidal effectiveness of two organophosphates and one carbamate insecticides against this pest. Also the residues behaviour of the sprayed compounds on tomato fruits by the lapse of time was studied to clarify the preharvest intervals (PHI's) to avoid health hazards. The residual behavior of pesticides was studied by several researchers i.e. Abd el-Rahman (2005), Abd El-Allem et al (2004), Hegazy et al (2004), Nasr and Hegazy (2003), EI Hadidi (2000) and Hegazy et al (1997).

1- Central Agricultural Pesticides Laboratory, Agricultural Research Center, Dokki, Giza, Egypt

(Received June 14, 2005)

(Accepted June 25, 2005) 
Arab Univ. J. Agric. Sci., Ain Shams Univ., Cairo, 13(3), 989 - 996, 2005

\section{MATERIAL AND METHODS Field experiment}

Tomato was planted on Feb $5^{\text {th }} 2005$ under the normal field conditions at Manshat Gansour, Tanta, El-Gharbia governorate. Three plots were sprayed on tomato fruit stage on $2^{\text {nd }}$ april 2005 at the recommended rate of the studied insecticides, i.e. chlorpyrifos-metlyl (reldan $50 \%$ EC $250 \mathrm{~cm}^{3} / 100 \mathrm{~L} \mathrm{H}_{2} \mathrm{O}$ ), profenofos (selecron $72 \% \mathrm{EC}$ $\left.187.5 \mathrm{~cm}^{3} / 100 \mathrm{~L} \mathrm{H}_{2} \mathrm{O}\right)$ and methomyl (lannate $90 \% \mathrm{SP} 75 \mathrm{gm} / 100 \mathrm{~L} \mathrm{H}_{2} \mathrm{O}$ ). The fourth plot was left untreated as control. Spraying of insecticide was done by using a knapsack sprayer equipped with one nozzle.

\section{Bioresidual activity}

Samples of tomato leaves were collected at $2 \mathrm{hr}$ (initial) and then after 1 , $3,6,9,13,16$ and 21 days from spraying. The bioresidual efficiency of the tested insecticides was evaluated on laboratory strain of $S$. littoralis. Ten larvae of each $2^{\text {nd }}$ and $4^{\text {th }}$ instars were allowed to feed on treated tomato leaves in a clean glass Jar. Three replicates were used at each interval. The same was done with the untreated control. The mortality of larvae was counted and recorded $24 \mathrm{hrs}$ later after feeding and corrected for natural mortality by using Abbot's formula (1925). (The average percent mortality of the two tested instars was used as the parameter indicating the bioresidual activity (persistence) of chlorpyrifosmethyl, profenofos and methomyl throughout the experimental period). Fruit Sampling for residue analysis

Samples of tomato fruits of 1000 $\mathrm{g} / \mathrm{plot}$ were taken in random. Three subsamples (replicates) of $100 \mathrm{~g}$ each were prepared and kept in polyethylene bags at deep freezer at $-20^{\circ} \mathrm{C}$ till insecticides residue analysis.

\section{Extraction and clean up}

The organophosphate insecticides chlorpyrifos-methyl and profenofos were extracted and cleaned-up according to the methods that adopted by Hegazy et al (1997) and Nasr and Hegazy (2003). On the other hand, the method of El-Hadidi (2000) was used for extraction and clean up of the carbamate methomyl from tomato fruits.

\section{Determination}

Chlorpyrifos-methyl and profenofos residues were determined by using Heweltt Packard 6890 gas chromatograph equipped with Flame Photometric detector (FPD) (p-mode), column PAS1701 (30mx $0.32 \mathrm{mmx} 0.25 \mu \mathrm{m}$ ).

Temperature programming was adjusted under the following conditions: injection $240^{\circ} \mathrm{C}$, column $230^{\circ} \mathrm{C}$ and detector $250^{\circ} \mathrm{C}$. The carrier gas was nitrogen at a flow rate $4 \mathrm{ml} / \mathrm{min}$, hydrogen at $75 \mathrm{ml} / \mathrm{min}$ and air at $100 \mathrm{ml} / \mathrm{min}$. Using these conditions, the retention times (Rt's)

1- Central Agricultural Pesticides Laboratory, Agricultural Research Center, Dokki, Giza, Egypt

(Received June 14, 2005)

(Accepted June 25, 2005) 
991

\section{Dissipation rate of certain insecticides on tomato}

values were 3.66 and $2.01 \mathrm{~min}$, respectively.

Methomyl residues were determined by using HPLC equipped with a UV detector, set at 254nm. C18 (Zorba SB $5 \mu \mathrm{m})$ Column was used. The mobile phase was freshly prepared as a mixture of acetonitrile/water (70:30) with the flow rate of $1 \mathrm{ml} / \mathrm{min}$. Under these operating conditions, the retention time of methomyl was $3.65 \mathrm{~min}$.

\section{Kinetic study}

In order to calculate the rate of degradation $(\mathrm{k})$ of the three tested insecticides and determine the half-life periods $\left(\mathrm{t}_{0.5}\right.$ 's) on tomato fruits, the equation of Moye et al (1987) was followed.

\section{RESULTS AND DISCUSSION}

\section{a) Bioresidual activities of the tested insecticides}

Data in Table (1) showed that the second and fourth instar larvae of $S$. littoralis were highly susceptible to chlorpyrifos-methyl and profenofos showing $100 \%$ mortality within the time intervals of 0,1 and 3 days after spraying. The mortality of larvae started to decline after 6 days to reach $82.5 \& 97.5 \%$, respectively. By the prolongation of post application, the average of mortality percent for chlorpyrifos-methyl and profenofos had declined gradually to be $39 \& 88.5 \% ; 22.5 \& 54.25 \%$ and $12.5 \&$ $17.5 \%$ after 9,13 and 16 days from spraying, respectively. No larval mortality was recorded after 21 days from spraying.
Data also indicated that profenofos was the highly toxic compound against both the $2^{\text {nd }}$ and the $4^{\text {th }}$ larval instars, achieving 100 and $95 \%$ mortality after six days from spraying, whereas chlorpyrifos - methyl caused 85 and $80 \%$ mortality at the same time interval.

The carbamate methomyl achieved $100 \%$ kill as initial against both instars of S. littoralis larvae. Such efficacy was continued against the two instars, showing 100 and $91.25 \%$ mortality after 1 and 3 days from application, respectively. By the progression of time, methomyl activity started to decline gradually and disappeared completely after 21 days ( 0 -mortality).

Figure (1) showed that profenofos achieved the highest $\mathrm{t}_{0.5}$ (time elapsed to achieve 50\% mortality) among the tested insecticides (14.3 days) followed by methomyl (10.25 days) and chlorpyrifosmethyl (8.15).

Our results are in agreement with those obtained by Abd-Allah (1998) who reported that chlorpyrifos-methyl had the highest toxicity to $S$. littoralis. El-Dahan (1991) found that methomyl was less potent than organophosphorus compounds against $S$. littoralis. Mourad et al (1991) reportd that different organophosphorus were more toxic than carbamate insecticides based on residual activity. The same trend of results was found by Bayoumi et al (2003) who found that chlorpyrifos-methyl was the most effective pesticides towards $S$. littoralis larvae followed by methomyl. Watson et al (1982) and Abdallah \& Shams El-Dine (1991) were obtained almost same performance of insecticides against the cotton leaf-worm larvae.

\section{b) Residues of the tested insecticides}


992

\section{Nevein and Amal}

Data in Table (2) indicated the initial deposits and residues of chlorpyrifosmethyl, profenofos and methomyl insecticides on tomato fruits. The obtained results showed that chlorpyrifosmethyl was found in the lowest levels of residue $(0.03 \mathrm{ppm})$ followed by profenofos $(0.22 \mathrm{ppm})$ and methomyl $(0.33 \mathrm{ppm})$ after 13 days from spraying. The three insecticides were completely disappeared by the end of experiment ( 21 days). 
Arab Univ. J. Agric. Sci., Ain Shams Univ., Cairo, 13(3), 989 - 996, 2005

Table 1. Bioresidual activities of chlorpytifos-methyl, profenofos, and methomyl on tomato plants against $2^{\text {nd }}$ and $4^{\text {th }}$ instars of S.littorallis larvae

\begin{tabular}{|cccccccccc|}
\hline $\begin{array}{c}\text { Intervals } \\
\text { (days) }\end{array}$ & \multicolumn{7}{c}{$\%$ Corrected mortality } \\
\hline \multicolumn{7}{c}{ Chlorpyrilos-methyl } & \multicolumn{7}{c|}{ Profenofos } & \multicolumn{3}{c|}{ Methomyl } \\
\hline & $2^{\text {nd }}$ & $4^{\text {th }}$ & Average & $2^{\text {nd }}$ & $4^{\text {th }}$ & Average & $2^{\text {nd }}$ & $4^{\text {th }}$ & Average \\
\hline Initial & 100 & 100 & 100 & 100 & 100 & 100 & 100 & 100 & 100 \\
$(2 \mathrm{hr})$ & & & & & & & & & \\
1 & 100 & 100 & 100 & 100 & 100 & 100 & 100 & 100 & 100 \\
3 & 100 & 100 & 100 & 100 & 100 & 100 & 95 & 87.5 & 91.25 \\
6 & 85 & 80 & 82.5 & 100 & 95 & 97.5 & 85 & 80 & 82.5 \\
9 & 43 & 35 & 39 & 90 & 87 & 88.5 & 56 & 52 & 45 \\
13 & 25 & 20 & 22.5 & 58.5 & 50 & 54.25 & 35 & 32 & 33.5 \\
16 & 15 & 10 & 12.5 & 20 & 15 & 17.5 & 10 & 10 & 10 \\
21 & 0.00 & 0.00 & 0.00 & 0.00 & 0.00 & 0.00 & 0.00 & 0.00 & 0.00 \\
\hline $\mathrm{t}_{0.5}$ & & 8.15 & & & 14.30 & & & 10.25 & \\
\hline
\end{tabular}

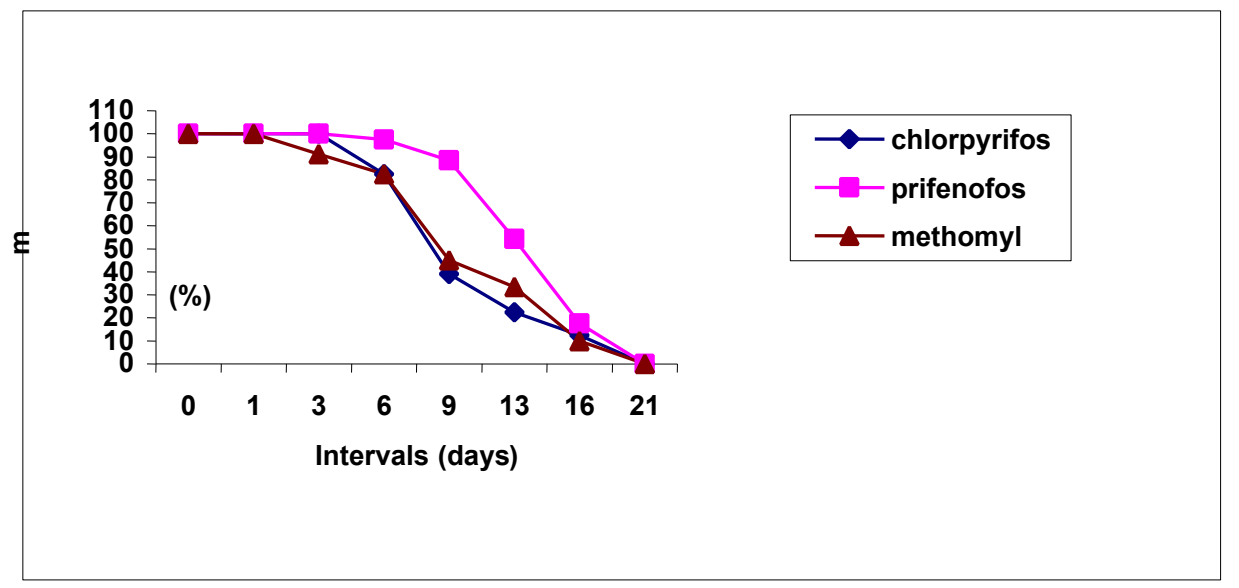

1- Central Agricultural Pesticides Laboratory, Agricultural Research Center, Dokki, Giza, Egypt

(Received June 14, 2005)

(Accepted June 25, 2005) 
Fig. 1. Bioesidual activities of Chlorpyrifos-methyl, profenofos and methomyl against S. littoralis

Table 2. Residues of chlorpyrifos-methyl, profenofos and methomyl on tomato fruits at different time intervals

\begin{tabular}{|c|c|c|c|c|c|c|}
\hline \multirow[t]{2}{*}{$\begin{array}{c}\text { Intervals } \\
\text { (days) }\end{array}$} & \multicolumn{2}{|c|}{ Chlorpyrilos-methyl } & \multicolumn{2}{|c|}{ Profenolos } & \multicolumn{2}{|c|}{ Methomyl } \\
\hline & $\begin{array}{l}\text { Residues } \\
\text { (ppm) }\end{array}$ & $\%$ loss & $\begin{array}{l}\text { Residues } \\
\text { (ppm) }\end{array}$ & $\%$ loss & $\begin{array}{c}\text { Residues } \\
\text { (ppm) }\end{array}$ & $\%$ loss \\
\hline $\begin{array}{l}\text { Initial } \\
(2 \mathrm{hr})\end{array}$ & 2.10 & 00.0 & 2.58 & 0.00 & 20.11 & 0.00 \\
\hline 1 & 0.74 & 64.77 & 1.41 & 45.35 & 14.98 & 25.21 \\
\hline 3 & 0.19 & 90.96 & 0.91 & 64.73 & 10.01 & 50.23 \\
\hline 6 & 0.10 & 95.24 & 0.61 & 76.36 & 5.91 & 70.62 \\
\hline 9 & 0.06 & 97.15 & 0.54 & 79.07 & 1.85 & 90.80 \\
\hline 13 & 0.03 & 98.58 & 0.22 & 91.48 & 0.33 & 98.36 \\
\hline 16 & UND & 100.00 & 0.09 & 96.52 & 0.01 & 99.50 \\
\hline 21 & UND & 100.00 & UND & 100.00 & UND & 100.00 \\
\hline MRL & \multicolumn{2}{|c|}{0.5} & \multicolumn{2}{|c|}{2} & \multicolumn{2}{|c|}{1} \\
\hline $\mathrm{k}$ & \multicolumn{2}{|c|}{1.4151} & \multicolumn{2}{|c|}{0.6753} & \multicolumn{2}{|c|}{0.5841} \\
\hline $\mathrm{t}_{0.5}$ & \multicolumn{2}{|c|}{0.4898} & \multicolumn{2}{|c|}{1.026} & \multicolumn{2}{|c|}{1.1867} \\
\hline
\end{tabular}

Initial : (Two hours after application)

UND : Undetectable

MRL : Maximum residue level

$\mathrm{k}$ : $\quad$ Rate of degradation

$\mathrm{t}_{0.5}: \quad$ Half-life period

The initial deposits (0-time) of chlorpyrifos-methyl, profenofos and methomyl were $2.10,2.58$ and 20.11 ppm, while decreased to $0.19,0.91$ and $10.01 \mathrm{ppm}$, respectively, after three days from application. This indicates that chlorpyrifos-methyl showed the most degradation behaviour $(90.96 \%)$, followed by profenofos $(64.73 \%)$ and methomyl (50.23\%) within this period. The variation in the degradation may be attributed to the insecticide type, applied rate, time after treatment,... etc. El-Sayed et al (1976), stated that the amounts of deposits depended on the rate of application, the nature of the treated 
Arab Univ. J. Agric. Sci., Ain Shams Univ., Cairo, 13(3), 989 - 996, 2005

surface and the relation between the treated surface and its weight. Gennari $\boldsymbol{e t}$ al (1985), also reported that the degradation was very dependent on climate factors including sunlight and daily temperature fluctuations.

According to CODEX (2003), the maximum residue levels of chlorpyrifosmethyl and profenofos on tomato fruits were 0.5 and $2.0 \mathrm{ppm}$, respectively, this indicates that only 3 and 1 days, respectively were enough for reaching the safe level for harvesting tomato after spraying by these two organophosphorus insecticides. But methomyl should be collected 13 days after treatment due to its high residues and MRL (1ppm).

The rate of degradation $(\mathrm{k})$ of chlorpyrifos-methyl, profenofos and methomyl were $1.4151,0.6753$ and 0.5841 days, respectively, and the calculated residue half-lives $\left(\mathrm{t}_{0.5}\right)$ were $0.4898,1.026$ and 1.1867 days, respectively.

Such results are in agreement with that reported by Hegazy et al (1997) who found that only three days was enough for the chlorpyrifos-methyl residues to reach a safe level less than the MRL of the CODEX (1993) (0.5 ppm).

Nasr and Hegazy (2003) indicated that profenofos residues on and in tomato fruits decreased from $2.45 \mathrm{ppm}$ to reach $0.19 \mathrm{ppm}$ after 15 days post-treatment revealing total loss of $92.24 \%$ of the initial deposits. The data further showed that the half-life $\mathrm{t}_{0.5}$ of profenofos was 23 hours.

Sahoo et al (2004) reported that the use of profenofos at the minimum effective dosages does not seem to cause any hazards to the consumers if waiting periods of 3 days is followed. Moreover, the consumer can further reduce the risk by washing the treated tomato fruits thoroughly with plain water before consumption. Gil Garcia et al (1997), stated that climatic conditions (growing season) and temperature are important in methomyl degradation. Similar findings were obtained by many investigators, Abd El-Rahman (2005), Abd El-Allem et al (2004), and Hegazy et al (2004).

As conclusion, it's more efficient to spray chlorpyrifos-methyl and profenofos for their low residues and lower preharvest intervals.

From the present work we should be pointed out that it is necessary to use safely and highly effective insecticides in controlling S. littoralis larvae which feed on tomato plant leaves to insure good yield of tomato fruits and safety to human being.

\section{REFERENCES}

Abbott, W.S. (1925). A method for computing effectiveness of an insecticide. J. Econ. Entom. 18: 265-267.

Abd-Allah, E.A. and A. Shams El-Dine (1991). Dissipation rate of methomyl in clover field and its bioresidual activity against the Egyptian cotton leaf worm $S$. Littoralis (Boisd). Bull. Fac. of Agric. Cairo Univ. 42(4): 1157-1168.

Abd-Allah, S.A.A. (1998). Toxicological Studies of Some Pesticides in Relation to Their Side Effects. pp. 45-55. M.Sc.

1- Central Agricultural Pesticides Laboratory, Agricultural Research Center, Dokki, Giza, Egypt

(Received June 14, 2005)

(Accepted June 25, 2005) 
thesis, Fac. Of Agric., Kafr El- Sheik, Tanta Univ.,Egypt.

Abd El-Allem, T.; M.I. Abd ElMegged; M.M. Almaz and S. Dahroug (2004). Residual behaviour of profenofos, prothiofos and fenitrothion certain organophosphorus insecticides on and in two varities of potato plants under field conditions. Research Bull., Fac. Agric., Ain Shams Univ., Cairo 27th July: 1-9.

Abdel-Rahman, T.A. (2005). Residues of Certain Pesticides in Potato. pp.: 8495. M.Sc. Thesis, Faculty of Agric. Ain Shams Univ., Cairo.

Bayoumy, O.C.; M.A. Ashry; M.M. ElNagar and F.L.L. Eissa (2003). Detrmination of some pesticides residues in watermillon plant and their toxic effect against some pests. J. Agric. Sci. Mansoura Univ. 28(3): 2243-2257.

Codex Alimentarius Committee for Pesticides Residues (CAC/PR) (1993). Guide to Codex Recommendation concerning pesticide of residues, maximum limits for pesticide residues. Thirty fifth sessions, Part 2, Rotterdam, Netherlands.

Codex Alimentarius Committee for Pesticides Residues (CAC/PR) (2003). Guide to Codex Recommendations concerning pesticide of residues, maximum limits for pesticide residues. Thirty fifth sessions., $5^{\text {th }}$ April pp: 90, 94, 171, Rotterdam, Netherlands.

El-Dahan, A.A. (1991). Resistance status of S. Littoralis (Boisd) to insecticides in Kafr El-Sheik Governorate during 19841988 cotton growing season. J. Agric. Sci. Res. 69(1): 23-30.

El-Hadidi, M.F. (2000). Methomyl residues on and in fresh and processed green pods of common bean and cowpea. Egypt. J. Appl. Sci. 15(3): 274-281.
El-Sayed, M.M.; S.M. Dogheim; S.A. Hindi; A. Shahin and Abdel-Salam (1976). Persistence of certain organophosphorus insecticide on some vegetables. Bull. Ent. Soc. Egypt. Econ. Ser. 10: 41-49.

Gennari, M.; E. Zannini; A. Cignetti ; C. Bicchi ; A.D. Amoto ; M.B. Taccheo ; C. Spessoro; M. De Paloi; P. Flori; G. Imbroglini; A. Leandri and E. Conte (1985). Vinclozolin decay on different grape vines in four different Italian areas, J. Agric. Food Chem. 33: 1232-1237.

Gil Garcia, M.D.; J.L. Martines Vidal and Martinez Galera (1997). Determination and degradation of methomyl in tomatoes and green beans grown in green houses. J. of $\boldsymbol{A O A C}$. 80(3): 633-638. 
Hegazy, M.E.A.; M.M. Abu Zahw; A.M. Bayoumy; S.A. Soliman and M.N.S. Haggag (1997). Effect of processing cucumber fruits on chlorpyrifos-methyl insecticide residues. Egypt. J. Agric. Res., 75(1): 51-59.

Hegazy, M.E.A.; A.M.R. Afify; A.A. Hammama and T.F.A. El-Refahey (2004). Effect of food processes pesticides in cucumber fruits. Egypt. $\boldsymbol{J}$. Agric. Res., 82(2): 525-544.

Mourad, M.A.; M.E. Omar and A.A. Mahran (1991). Toxicity and residual action of certain insecticides against the cotton leaf worm S. Littoralis (Boisd). Egypt. J. Agric. Rec. 69(1): 49-56.

Moye, H.A.; M.H. Malagod; J.Yoh; G.L. Leibee; C.C. Ku; and P.G.Wilslocki (1987). Residues of avermectin $\mathrm{B}_{\mathrm{a}} \mathrm{a}$ : Rotational crop and soils following soil treatment with $\left(\mathrm{C}_{14}\right)$ Avermectin $\mathrm{B}_{\mathrm{l}}$ a. Agric. Food Chem., 35: 859-864.
Nasr, I.N. and M.E.A. Hegazy (2003). Residues and half-lives of certain insecticides on and in some vegetable under field conditions. Egypt. J. Agric. Res., 81(1): 83-92.

Sahoo, S.K.; S.K. Kapoor and B.Singh (2004). Estimation of residues of profenofos in/on tomato, Lycopersicon. Esculentum Mill. Environmental Contamination and Toxicology 72(5): 970-974.

Tomlin C.D.S. (2000). The Pesticide Manual, published by British Crop Protection Council (BCPC) $12 \boldsymbol{E d}$. pp. 145, 324 and 502, London, UK.

Watson, M.; A.A. El-Dahan and F.A. Khalil (1982). Potenices of dimilin and altosid in combination with some insecticides against $S$. Littoralis Proc. Egypt's National Conf. Ent., 1: 687-699. 
Arab Univ. J. Agric. Sci., Ain Shams Univ., Cairo, 13(3), 989 - 996, 2005

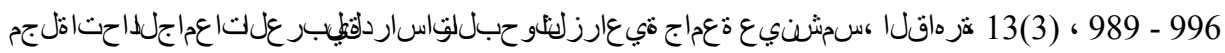
، 2005

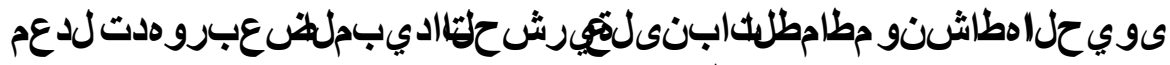
نطقل

]67[

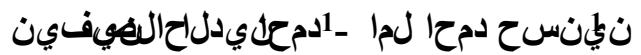

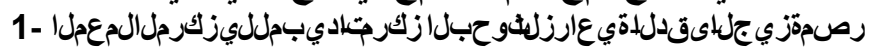

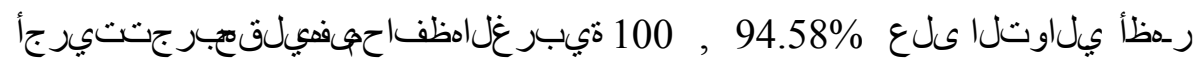
تاديبمله-يلولثاليقبت

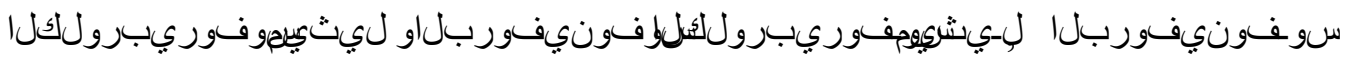
2.1 2.58, 20.11 , 2.19

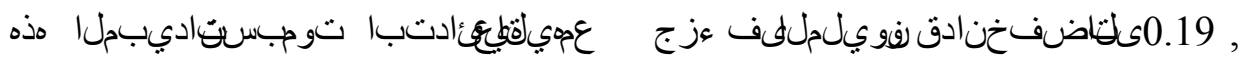

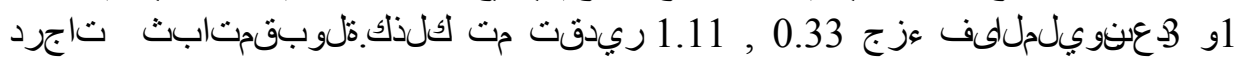
دذهن الئىلاوتلایىعشرلا نمجوي 13و تات

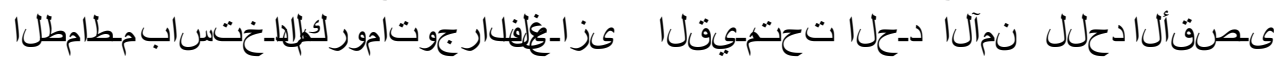

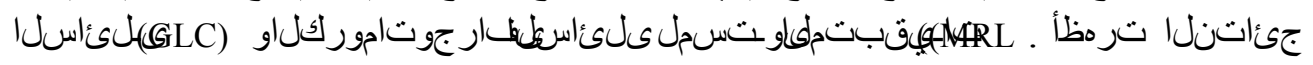

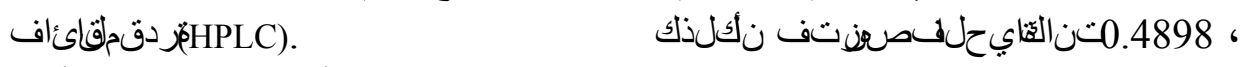

تاد_يبجل موي 1.1867 ، 1.026 ة 1.026

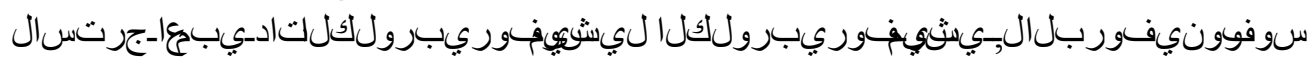

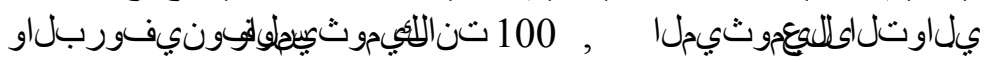

ديملابع عىنهناديز د:ألميكحت

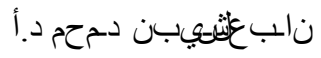

1- Central Agricultural Pesticides Laboratory, Agricultural Research Center, Dokki, Giza, Egypt

(Received June 14, 2005)

(Accepted June 25, 2005) 